\title{
POLITENESS IMPLICATURE ON SHORT MESSAGE SERVICE (SMS) TEXT WRITTEN BY COLLEGE STUDENTS SENT TO THEIR LECTURERS AS A MEDIA DEVELOPMENT OF AFFECTIVE ASSESSMENT IN HIGHER EDUCATIONS
}

\author{
Eko Suroso \\ Universitas Muhammadiyah Purwokerto \\ Jawa Tengah, Indonesia \\ Email: eko_suroso45
}

\author{
Sarwiji Suwandi \\ Universitas Sebelas Maret Surakarta \\ Jawa Tengah, Indonesia \\ email: sarwijiswan@staff.uns.ac.id \\ Sumarlam \\ Universitas Sebelas Maret Surakarta \\ Jawa Tengah, Indonesia \\ Email: sumarlamwd@gmail.com
}

\begin{abstract}
Implicature is an implicit aspect on human communication. Text of short message service written by students of higher education (collage students) sent to their lecturers is a linguistic data that can be utilized to figure out politeness implicature of the students. Knowledge of students' politeness is important, because it is one of affective assessment forms that is not recently noticed in higher educations. The problems are: 1) how is the form of implicature of students' SMS text sent to their lecturers? 2) How is the impoliteness form of the students' SMS text? This research was conducted using descriptive qualitative approach. The descriptive approach was in form of SMS text data presentation done by the researcher. While the qualitative approach was in form of interpretation of politeness or impoliteness on the available data (SMS text). The research data were the students' SMS texts sent to their lecturers. Its data resources were submitted from the lecturers working at three big universities located in Banyumas regency. Data collection was conducted using documentation technique. Data analysis was conducted using triangulation technique. Research result showed that the students' SMS texts are commonly written in less polite tone. The lack of politeness in the SMS texts could be viewed from the time limitation proposed by the students to their lecturers. The form of impoliteness occurred because of maxim violation such as: tact maxim, generosity maxim, modesty maxim, agreement maxim, sympathy maxim, and approbation maxim.
\end{abstract}

Keywords: implicature, SMS, and politeness.

\section{BACKGROUND}

In human communication (especially the written communication), intention or meaning owned by the communicators containing direct and indirect meaning. It is better for a communicator to meet rules of communication in his/her communication in order to be understood by communicants easily (Tan, Teoh, Tan, 2016: 175). However, the communicator sometimes breaks the rules intentionally or unintentionally. It causes occurance of implicit factor in communication (García, C. S. 2017: 19). In addition, there may be an implication in form of proposition which is not actually a part of the speeches in a conversation. On the other words, implication of communication in a conversation can be understood from what may be interpreted, implied or intended (Allan, K. 2016: 10).

Written communication in form of SMS texting contains a lot of implicature meaning because punctuations used in the texts are not able to represent speech expression of the speaker. Therefore, miscommunication and misunderstanding are very vulnerable to occur in SMS texting communication. Here is the example of SMS texting As. Wr. Wb. Maaf pak besok saya mau bimbingan ke Bapak. Bapak ada waktu jam berapa ya? Ws. Wr. Wb (As. Wr. Wb. Sorry Sir, tomorrow I plan to have thesis supervision with you. What time are you available? Ws. Wr. Wb). This short 
message shows a time dictation of the communicator (the SMS text sender) to the communicant (SMS text receiver). The time dictation is in sentence Maaf pak besok saya mau bimbingan ke Bapak (Sorry Sir, tomorrow I plan to have thesis supervision with you). In fact, the text is commonly spoken (or written) by a boss to his/her employees, such as Maaf besuk saya akan datang. Tolong berkas-berkas disipakan. (Sorry, I have to come tomorrow, please prepare the files). In fact, the SMS text above is written and sent by a student, someone who needs thesis supervision. It should not be done by someone who needs thesis supervision to dictate the supervisors. Therefore, it implicitly contains impoliteness. As a student who needs to meet his/her thesis supervisor, the written sentences restricting others (in a context of appointment making with someone) should not be used. The SMS text would be better in such way: As. Wr. Wb. Maaf pak, saya mau bimbingan ke Bapak. Kapan kira-kaira Bapak ada waktu? Ws. Wr. Wb. (As. Wr. Wb. Sorry Sir, I plan to meet you to have thesis supervision. When is your available time? Ws. Wr. Wb.)

In the SMS text, it was possible that the SMS text sender did not intentionally dictate the communicant (the SMS text receiver), but the written text dictated the communicant implicitly. Such pragmatic case can be an aspect of affective assessment done by the lecturers toward their students, because the lecturers' responsibility is not only assessing their students in cognitive and psychomotor aspects, but also their affective aspect. Affective assessment can be implemented gradually; it is for assessment of various students' behavior, and takes long time (Chiravate, 2011: 61). Therefore, a lecturer should have a special note book to record his/her students' behavior. To set students' SMS text as an alternative of affective assessment, a lecturer may not directly judge his/her students negatively once the students sent the SMS text containing impolite written epression; the lecturer should remind and educate the students while delivering regular lectures. Based on the phenomena, the research problem that occurs are: 1) how is the form of implicature of students' SMS text sent to their lecturers? 2) How is the impoliteness form on the students' SMS text sent to their lecturers?

The implicature is an implied meaning that arises as a result of a context. The context in this case is who speaks, to whom he/she speaks, when he/she speaks, what is spoken, and where to speak. The same sentence when it is spoken in different contexts will have different meanings (Holtgraves, 1997: 113). The term of implicature was used by Grice in 1967 to solve the problem of language meaning that cannot be solved by ordinary semantic theory (Grice, I967: 45). Implicature comes from a verb to imply while its noun form is implication. This verb comes from a Latin language "plicare" which means to fold, so to understand what is folded or stored, it must be done by opening it (Maros,
Rosli. 2017: 137). Understanding what a speaker means, the opponent should always interpret the speech. Cummins, Sauerland, and Solt, (2012: 143) atated that implicature is an additional meaning of information delivered. It is also in line with the statement of Rohmadi \& Wijana (2009:222); the statement said that implicatures are utterances or statements that imply a meaning which is different from what is actually spoken. Thus, implicature is an implied meaning that arises as a result of context.

Affective scope is a domain associated with attitudes and values (Rido, Ibrahim,. 2015: 87). Some experts say that a person's attitude can be predicted to change, if he/she already has a high level of cognitive mastery. Characteristics of affective learning outcomes appear in various behaviors such as: attention to the subject, discipline in following the learning process, motivation in learning, appreciation or respect for teachers, and so on (Khan, Bughio, 2012: 27). Department of National Education of the Republic of Indonesia (2008: 3) categorized affective scope in five levels including: (1) accepting and paying attention, (2) responding, (3) assessing, (4) managing, and (5) characterizing a value or a group of value. There are five important affective characteristics: attitude, interest, selfconcept, value and moral.

Relating to the use of SMS text as a medium of affective assessment development, the method of observation is more appropriate to use, because its data collection is not limited to a certain time, but it can be in a long time. Every SMS text sent by the students should be noted in a special note book that has been prepared by the lecturers and concerned to then analyze its politeness. The analyzed SMS text is then classified into polite and impolite category. The impolite SMS texts are then classified based on the maxim violations as its causes. Commonly, the impoliteness occurs because of cooperative principle violation and /or politeness principle (Spector1 \& Sudo, 2017: 14). The cooperative principle is divided into four maxims including: (1) maxim of quality, (2) maxim of quantity, (3) maxim of relevance, and (4) maxim of manner (Grice 1975: 45). Maxim of quantity is the provision of sufficient information (not excessive). Maxim of quality is the provision of actual information that is based on fact or data. Maxim of relevance is the provision of information appropriate to the topic of conversation. Maxim of manner is to provide information with certain techniques to avoid miscommunication or misunderstanding. Leeach (1989: 16) divided cooperative principles into six maxims: (1) tact maxim, (2) generosity maxim, (3) munificence maxim, (4) modesty maxim, (5) agreement maxim, (6) sympathy maxim.

\section{RESEARCH METHOD}

This research was conducted using descriptive qualitative approach. In implementing descriptive 
approach, the researcher describes, explain, and present the data as it is in form of students' SMS text. While in qualitative approach, the researcher did interpretations to figure out both politeness implicature and impoliteness implicature on data research. The data were students' SMS text sent to their thesis supervisors. Data resources of this research were the students. The data collection technique was done using technique of documentation observation. The documentation was SMS text owned by the thesis supervisors/lecturers. In this case, the researcher did not take any treatment on the data. Observation technique was conducted by noting every student's SMS text received by the lecturers in Universitas Muhammadiyah Purwokerto, the campus where the researcher works. The SMS texts were obtained from all lecturers in 31 departments at Universitas Muhammadiyah Purwokerto. Each SMS text student sent to the lecturers was forwarded to the researcher's mobile phone. The research analysis employed equivalent method; it was by comparing elements outside the language itself.

The determinant employed in this method was ferential equivalent method; it was a technique to correlate and compare denotative meaning and certain interpretative sense value. In addition, it also employed contextual method; it was correlating to the conversation context (when data of SMS text sent, to whom, where, and in what conversation topic). Data interpretation was done using researcher's triangulation technique. In this case, the researcher compared his interpretation toward data implicature (SMS text) with the interpretation of researcher members. If then the difference was found, it would be discussed together to meet the closest logic of its meaning. If the interpretation difference had its meaning logic, all of different interpretation results would be implicature variants.

\section{DISCUSSION}

\section{A. Several Polite SMS Texts Sent by Students}

One of aims of politeness in communication is to make the atmosphere of interaction fun and effective (Geurts etc al, 2010: 137). According to Rifai, Sudargono, \& Sukamto (2013: 281), politeness is a behavior expressed in a good or ethical way. The following data of SMS text was categorized as a polite message, because the sender really appreciated the receiver by writing: greeting, apology, and brief self introduction before the sender wrote his/her message intention.

Assalamu'alaikum Maaf pak, Saya mengganggu. Saya (Rini mhs sem 8A) mau bimbingan judul skripsi dengan bapak. Kapan bapak ada waktu? (data 1)

Assalamu'alaikum Sorry Sir for interrupting you. I am Rini ( $8^{\text {th }}$ A semester student). I would like to have thesis supervision with you. Would you mind to inform me your available time? (data 1)
The politeness could be viewed from the text; it seems not dictating his/her supervisors. It could be viewed from data Kapan bapak ada waktu? 'Would you mind to inform me your available time?' The question implied that the sender was willing to adapt his/her time availability with the SMS receiver (supervisor/lecturer).

If a conversation involves two participants, it will run fluently due to agreement of both communication participants/speakers (Stevens \& Kristof, 1995:589). The agreement can be such non written agreement that the discussed topic should be correlating each other. Other agreement was such existence of politeness contract both in utterance and action. On the third data, it seems that the dictions used were in polite forms.

Ass. Wr. Wb. Maaf Bu saya mau bimbingan skripsi, kapan sy.bs ketemu Ibu? Eni Nurina sem $9 A$ (data 3).

'Ass. Wr. Wb. Sorry Mom, I would like to have thesis supervision with you. When can I meet you? Eni Nurina $9^{\text {th }}$ semester 9A

(data 3)

According to Nurjamily (2015: 15), politeness is not only expressed on the utterance content, but also in the way the utterances spoken by the speakers. Based on politeness maxim of Leech, the SMS text of data 3 did not break the principle of modesty, because the sender put herself lower than the SMS text reeiver. In addition, the text began with Maaf 'Sorry'. It indicated that the sender felt she interrupted the receiver's business. The sender did not dictate the receiver because she put her identity on her SMS text.

Some others SMS texts that have met politeness standards and/or had no maxim violation were as follow:

1. Assalamualaikum. maaf mengganggu waktunya sebentar bu. ini saya Desiana,mau menanyakan apa sekripsi saya sudah selesai dikoreksi dan bisa bimbingan lagi bu? Terimakasih. (data 19)

'Assalamualaikum, sorry for interrupting you Mom. Its me Desiana, I would like to ask you whether you have finished checking my thesis or not, and can I meet you again for the next supervision? Thank you'. (data 19)

2. Assalamualaikum, wr.wb, maaf pak mengganggu, ni Yanti mau tanya besok hari selasa ada bimbingan apa tidak pak? Wassalam. (data 41)

'Assalamualaikum, sorry for interrupting you Sir, this is yanti, I would like to confirm you. Will we have supervision schedule on Tuesday Sir?' (data 41)

3. Assalamualaikum, maaf mengganggu, ni yanti,pak saya sudah didepan gedung g. Bpak dimana? (data 62)

'Assalamualaikum, sorry for interrupting, it's me yanti, I have been in the front of $g$ building. Where are you Sir?' (data 62) 
4. Assalamualaikum pak eko, ini saiful pak, maaf mengganggu kesibukan Bpk, kalo mau bimbingan lagi kira2 hari apa dan jam berapa ya pak? Trima kasih. (data 65)

'Assalamualaikum Mr. Eko, it's me saiful Sir, sorry for interrupting your business, if I plan to have another thesis supervision with you, what time would you be available for me Sir? Thank you.' (data 65)

5. Assalamu'alaikum warahmatullohi wabarokatuh. Maaf pak mengganggu, Pak besok kelas pbsi $2 \mathrm{~A}$ ada kuliah atau tidak? Edi sem 2A. Trims. (data 73) 'Assalamu'alaikum warahmatullohi wabarokatuh. Sorry Sir for interupting you, are you going to attend the class of PBSI 2A tomorrow? Edi sem 2A. Thanks.' (data 73)

Some of the data of SMS text above have met politeness standards because there were not maxim violation, especially cooperative maxim, mentioning identity, apologizing, saying the message intention, and saying thanks.

\section{B. Several Impolite SMS Texts.}

Impoliteness usually occurs because of maxim violation. According to Scheuer, J. (2001: 227), politeness principles and their sub-maxims consist of six types. They are: tact maxim, approbation maxim, generosity maxim, modesty maxim, agreement maxim, sympathy maxim.

Ass wr wb,maaf bu ngganggu nanti jam 9 B Daryati dr PPKHB Sokaraja mau menghadap IBU untuk minta tanda tangan SKRIPSI terima kasih (data 3).

'Ass $w r w b$, sorry Mom for interrupting you, I am Daryati from 9 B of PPKHB Sokaraja, I plan to meet you for your signature on my thesis, thank you.' (data 3)

Based on Scheuer's statment, the SMS text above breaks politeness principle, especially modesty maxim because the sender determined the time of the meeting, at 9 o'clock. Someone who plans to meet someone others and he/she decides the time of the meeting is usually done by a boss to his/her employees. The SMS text of data 3 is not such the case, but a relationship between a student and her lecturer.

Violation of politeness principle of sympathy maxim occurred in data 2 as follow: kpn? (data 2)

Ass. Wr. Wb.Bu Bgmn skripsi sy.bs ketemu

'Ass. Wr. Wb. Mom, how about my thesis? When can I meet you?' (data 2)

Based on politeness principle, the SMS text above broke modesty maxim, because the sender assumed that he/she was equal with the receiver. The SMS text was too short; it was such texts sent to peers. A student, whatever his/her job or social status, is socially lower than his/her lecturer. Therefore, students shoud respect their lecturers both in utterences (communication way) and attitude. Someone who respect other would not put his/herself equally with the respected. It was such an appreciation to others.

Violation of politeness principle also occured in data of SMS text number 4 as follow. The violation could be viewed from the time determination of thesis supervision at 11 o'clock by the SMS text sender.

Assalaamu'alaikumwrwb.Maaf bu.besuk sy bimbingan b.Tut pk11.Apa bisa ibu bsk ada waktu bimbingan sekaliyan untuk saya. Dari Parwati.(data 4)

'Assalaamu'alaikumwrwb. Sorry Mom, tomorrow I have thesis supervision with you (Mrs. Tut) at 11 o.clock. Are you available at the time. From Purwati.' (data 4)

Someone who keeps modesty maxim should not dictate the time of meeting such the data number 4 . If we plan to meet someone, better for us to adapt the time we have with someone's, so it is not necessary to determine the time first; better for us to adapt the time availability of others.

Data number 5 also an example of tact maxim violation:

Aslamulaikum bpk maaf nanti bsa bmbgan apa nggak pak? (data 5)

'Aslamulaikum Sir, can we have thesis supervision soon?' (data 5)

Tact maxim is a conversation where one of the speaker tries to minimize the advantages for his/herself, and to maximize the advantages of others (Ismail, 201: 2011). While the sentence used in data 5 did not have an effort to maximize the advantages of others, but vice versa. The sender assumed that the receiver is his/her close friend; in fact the SMS text receveiver was his/her lecturer. The effort to minimize other's advantages can be viewed from the statment nanti bsa bmbgan apa nggak pak. 'Sir, can we have thesis supervision soon'.

\section{Students' Politeness on SMS Text as A Developing Media for Affective Assessment.}

Affective assessment is an assessment to figure out level of someone's attitude value (Norafini \& Kaur, 2014: 111). In assessing the attitude, there are four levels used as assessment scale, they are: very polite (score 4), polite (score 3), polite enough (score 2), and impolite (score 1) (Kerekes, 2006: 29). An SMS text can be classified very polite if the text does not break maxim of both cooperative and politeness principles. An SMS text is categorized as polite if it breaks one maxim of cooperative or politeness principle. An SMS text is categorized as polite enough if it breaks two maxims of cooperative or politeness principle. An SMS text is categorized as impolite if it breaks more than two maxims of cooperative or politeness principle.

\section{CONCLUSION}

An SMS text is categorized as enough if it does not break available maxims of cooperative or 
politeness principle. Cooperative principles consisted of four maxims including: (1) maxim of quality, (2) maxim of quantity, (3) maxim of relevance, and (4) maxim of manner. Politeness principles consisted of six maxims: (1) tact maxim, (2) generosity maxim, (3) munificence maxim, (4) modesty maxim, (5) agreement maxim, (6) sympathy maxim. The implication on its assessment were very polite (score 4 ) if the SMS text does not break maxims, polite (score 3) if the SMS text break one maxim, polite enough (score 2) if the SMS text break two maxims, and impolite (score 1) if it breaks more than two maxims of cooperative or politeness principle.

\section{REFERENCES}

Allan, K. 2016. Contextual determinants on the meaning of the N word. SpringerPlus, 5 (1), 1-11.

Chiravate, B. 2011. Perception of politeness in English requests by Thai EFL learners. 3L: The Southeast Asian Journal of English Language Studies. 17 (2): 59-71.

Culpeper, J., et al. (2010). Cross-cultural variation in the perception of impoliteness: A study of impoliteness events reported by students in England, China, Finland, Germany and Turkey. Intercultural Pragmatics, 7(4), 597-624.

Cummins, C., Sauerland, U., Solt, S. 2012. Granularity and scalar implicature in expressions. Linguist and Philos. 35 (2), 135-169.

García, C. S. 2017. Emotional and Educational Consequences of (Im) politeness in TeacherStudent Interaction at Higher Education. Corpus Pragmatics, 10 (2), 1-23.

Geurts, B., Katsos, N., Cummins, C., Moons, J., \& Noordman, L. (2010). Scalar quantifiers: Logic, acquisition, and processing. Language and Cognitive Processes, 25 (1), 130-148.

Grice, H. P. 1975. Logic and Conversation. Syntax and Semantics, 3 (2) 41-58.

Haugh, M. (2010). When is an email really offensive? Argumentativity and variability in evaluations of impoliteness. Journal of Politeness Research, 6(1), 7-31.

Hyde, R. M., \& Flournoy, D. J. (1986). A case against mandatory lecture attendance. Journal of Medical Education, 61(3), 175-176.
Holtgraves, T. 1997. Politeness and memory for the wording of remarks. Memory \& Cognition. 25 (1), 106-116.

Ismail, N. A. (2011). Graduates' characteristics and unemployment: a study among Malaysian graduates. International Journal of Business and Social Science. 2 (16), 168-182.

Kerekes, J. (2006). Winning an interviewer's trust in a gatekeeping encounter. Language in Society. Vol. $35,27-57$.

Khan, Q., Bughio, F.A. 2012. Nunnery Scene: A Pragmatic Analysis of Hamet-Ophelia Encounter. 3L: The Southeast Asian Journal of English Language Studies. 18 (2), 25 - 34.

Lipovsky, C. (2006). Candidate's negotiation of their expertise in job interviews. Journal of Pragmatics. Vol.38, 1147-1174.

Mason, J. D., Healy, A. F., \& Marmie, W. R. (1996). The effects of rounding on memory for numbers in addition problems. Canadian Journal of Experimental Psychology, 50(3), 320-323.

Maros, M., Rosli L. 2017. Politeness Strategies in Twitter Updates of Female English Language Studies Malaysian Undergraduates. 3L: The Southeast Asian Journal of English Language Studies. 23 (1): $132-149$.

Mason, J. D., Healy, A. F., \& Marmie, W. R. (1996). The effects of rounding on memory for numbers in addition problems. Canadian Journal of Experimental Psychology, 50(3), 320-323.

Matsumoto, Y. (1988). Reexamination of the universality of Face: Politeness phenomena in Japanese. Journal of Pragmatics, 12, 403-426.

Mboudjeke, J. (2010). Linguistic politeness in job applications in Cameroon. Journal of Pragmatics. Vol. 42, 2519-2530.

Norafini Z. \& Kaur, S. (2014). Oral English communication difficulties and coping strategies of Diploma of Hotel Management students at UiTM. 3L: The Southeast Asian Journal of English Language Studies. Vol. 20 (3). 93-112.

Nouwen, R. (2008). Upper-bounded no more: The exhaustive interpretation of non-strict comparison. Natural Language Semantics, 16(4), 271-295. 
Nurjamily, W. O. (2015). Kesantunan Berbahasa Indonesia Dalam Lingkungan Keluarga (Kajian Sosiopragmatik). Jurnal Humanika, 15 (3) 1-18.

Partington, A. (2014). Mind the gaps. The role of corpus linguistics in researching absences. International Journal of Corpus Linguistics, 19(1), 118-146.

Rido, A., Ibrahim, N. 2015. Interaction Strategies of Master Teachers in Indonesian Vocational Classroom: A Case Study. 3L: The Southeast Asian Journal of English Language Studies. 21 (3): 85-98.

Rifai, M. H., Sudargono, A., dan Sukamto. (2013). Social Intercourse Etiquette of University Students of Teacher Training and Education Faculty in the academic year of 2012. Jurnal Pendidikan, 22 (3) 277-284.

Santamar1'a-Garci'a, C. (2011). Bricolage assembling: $\mathrm{CL}, \mathrm{CA}$ and DA to explore the negotiation of agreement in English and Spanish conversation. International Journal of Corpus Linguistics, 16(3), 346-371.

Scheuer, J. (2001). Recontextualization and communicative styles in job interviews. Discourse Studies. 3 (2), 223-248.

Spector1, B., Sudo2, Y. 2017. Presupposed ignorance and exhaustification: How scalar implicatures and presuppositions interact?. Linguist and Philos, 12 (2), 1-45.

Stevens, C.K. \& Kristof, A.L. (1995). Making the right impression: A field study of applicant impression management during job interviews. Journal of Applied Psychology. Vol. 80, 587-606.

Tan, H.K., Teoh, M.L., Tan, S.K., 2016. Beyond 'Greeting' and 'Thanking': Politeness in Job Interviews. 3L: The Southeast Asian Journal of English Language Studies , 22(3): 171 - 184. 